\title{
Floating stones off El Hierro, Canary Islands: xenoliths of pre-island sedimentary origin in the early products of the October 2011 eruption
}

\author{
V. R. Troll ${ }^{1,2}$, A. Klügel ${ }^{3}$, M.-A. Longprée ${ }^{4}$, S. Burchardt ${ }^{1}$, F. M. Deegan ${ }^{1,5}$, J. C. Carracedo $^{6}$, S. Wiesmaier ${ }^{7}$, \\ U. Kueppers ${ }^{7}$, B. Dahren ${ }^{1}$, L. S. Blythe ${ }^{1}$, T. H. Hansteen ${ }^{8}$, C. Freda ${ }^{2}$, D. A. Budd ${ }^{1}$, E. M. Jolis ${ }^{1}$, E. Jonsson ${ }^{1,9}$, \\ F. C. Meade ${ }^{1,10}$, C. Harris ${ }^{11}$, S. E. Berg ${ }^{1}$, L. Mancini ${ }^{12}$, M. Polacci ${ }^{13}$, and K. Pedroza ${ }^{1}$ \\ ${ }^{1}$ Dept. of Earth Sciences, CEMPEG, Uppsala University, Sweden \\ ${ }^{2}$ Istituto Nazionale di Geofisica e Vulcanologia, Rome, Italy \\ ${ }^{3}$ Institute of Geosciences, University of Bremen, Germany \\ ${ }^{4}$ Dept. of Earth and Planetary Sciences, McGill University, Canada \\ ${ }^{5}$ Laboratory for Isotope Geology, Swedish Museum of Natural History, Stockholm, Sweden \\ ${ }^{6}$ Dept. of Physics (Geology), GEOVOL, University of Las Palmas, Gran Canaria, Spain \\ ${ }^{7}$ Dept. of Earth and Environmental Sciences, Ludwig-Maximilians Universität (LMU), Munich, Germany \\ ${ }^{8}$ Leibniz-Institute for Oceanography, IFM-GEOMAR, Kiel, Germany \\ ${ }^{9}$ Geological Survey of Sweden, Uppsala, Sweden \\ ${ }^{10}$ School of Geographical and Earth Sciences, University of Glasgow, UK \\ ${ }^{11}$ Department of Geological Sciences, University of Cape Town, South Africa \\ ${ }^{12}$ SYRMEP Group, Sincrotrone Trieste S.C.p.A, Basovizza, Trieste, Italy \\ ${ }^{13}$ Istituto Nazionale di Geofisica e Vulcanologia, Sezione di Pisa, 56124 Pisa, Italy
}

Correspondence to: V. R. Troll (valentin.troll@geo.uu.se)

Received: 18 November 2011 - Published in Solid Earth Discuss.: 1 December 2011

Revised: 27 February 2012 - Accepted: 27 February 2012 - Published: 13 March 2012

\begin{abstract}
A submarine eruption started off the south coast of El Hierro, Canary Islands, on 10 October 2011 and continues at the time of this writing (February 2012). In the first days of the event, peculiar eruption products were found floating on the sea surface, drifting for long distances from the eruption site. These specimens, which have in the meantime been termed "restingolites" (after the close-by village of La Restinga), appeared as black volcanic "bombs" that exhibit cores of white and porous pumice-like material. Since their brief appearance, the nature and origin of these "floating stones" has been vigorously debated among researchers, with important implications for the interpretation of the hazard potential of the ongoing eruption. The "restingolites" have been proposed to be either (i) juvenile high-silica magma (e.g. rhyolite), (ii) remelted magmatic material (trachyte), (iii) altered volcanic rock, or (iv) reheated hyaloclastites or zeolite from the submarine slopes of El Hierro. Here, we
\end{abstract}

provide evidence that supports yet a different conclusion. We have analysed the textures and compositions of representative "restingolites" and compared the results to previous work on similar rocks found in the Canary Islands. Based on their high-silica content, the lack of igneous trace element signatures, the presence of remnant quartz crystals, jasper fragments and carbonate as well as wollastonite (derived from thermal overprint of carbonate) and their relatively high oxygen isotope values, we conclude that "restingolites" are in fact xenoliths from pre-island sedimentary layers that were picked up and heated by the ascending magma, causing them to partially melt and vesiculate. As they are closely resembling pumice in appearance, but are xenolithic in origin, we refer to these rocks as "xeno-pumice". The El Hierro xenopumices hence represent messengers from depth that help us to understand the interaction between ascending magma and crustal lithologies beneath the Canary Islands as well as in 
similar Atlantic islands that rest on sediment-covered ocean crust (e.g. Cape Verdes, Azores). The occurrence of "restingolites" indicates that crustal recycling is a relevant process in ocean islands, too, but does not herald the arrival of potentially explosive high-silica magma in the active plumbing system beneath El Hierro.

\section{Introduction}

On 10 October 2011, a submarine eruption commenced off the south coast of El Hierro (Fig. 1), the westernmost and youngest island of the Canaries (1.12 Ma; Guillou et al., 1996). Surface expressions of this eruption, the first to be witnessed at El Hierro, included green discolouration of seawater (locally known as "la mancha"; Fig. 1) along with strong bubbling and degassing. Two distinct types of eruptive products were observed at different stages of the eruption: (1) abundant rock fragments resembling lava bombs on a decimetre scale, characterised by glassy basanitic crusts and white to cream coloured interiors, were found floating and drifting on the ocean surface during the first days of the eruption; (2) entirely basanitic "lava balloons", frequently exceeding $1 \mathrm{~m}$ in size, often with hollow interiors, were sampled by ship while temporarily floating above the emission centre in the later phase of the eruption (e.g. November onward; IGN, 2011).

In this paper, we focus on the former type of samples, the highly buoyant rocks that have become locally known as "restingolites" after the nearby village of La Restinga (Fig. 1b). The first of these samples were collected by ship as early as 15 October (IGN, 2011). We sampled the specimens presented here for textural, mineralogical, elemental, and isotopic analysis between 21 and 28 October 2011 on El Hierro's south coast. The interiors of these floating rocks are light in colour, glassy and vesicular (similar to pumice), and mingling between the pumice-like interior and the enveloping basanitic magma is frequently observed. The nature and origin of these vesiculated interiors have been discussed by the scientific community to be either: (i) juvenile and potentially explosive high-silica magma, (ii) fragments of marine sediment from the submarine flank of El Hierro, or (iii) relatively old, hydrated and remobilised volcanic material (see e.g. Coello Bravo, 2011; Gimeno, 2011). However, none of these interpretations provides a perfect fit to the available observations, since, for instance, high-silica volcanism is uncommon on El Hierro (cf. Pellicer, 1979; Carracedo et al., 2001), and magmatic minerals (either grown in magma or as detritus from erosion) are entirely absent in the "restingolites". Considering that the presence of highly evolved, high-silica magmatism would have implications for the explosive potential of the eruption, it is important to clarify the nature of the early floating stones in order to fully assess the hazards associated with the ongoing El Hierro eruption. The results of our textural, mineralogical, elemental and isotopic analysis lead us to conclude that the early floating stones of El Hierro are vesiculated crustal xenoliths that originate from the substantial layer of sub-volcanic pre-island sedimentary rocks (layer 1 of the oceanic crust) that is present underneath the Canary archipelago.

\section{Analytical methods}

\subsection{Imaging and micro-analysis: Electron Probe Micro-Analyser}

Scanning electron microscopy (SEM) imaging and microanalysis of the early El Hierro "restingolites" was carried out at the Centre for Experimental Mineralogy, Petrology and Geochemistry (CEMPEG) at Uppsala University, Sweden, using a JXA-8530F JEOL HYPERPROBE field emission electron probe micro-analyser (FE-EPMA). The FE-EPMA is equipped with four wavelength-dispersive spectrometers (WDX) and secondary and backscattered electron detectors. Microprobe EDX analyses were performed using an accelerating voltage of $15 \mathrm{kV}$, a beam current of $5 \mathrm{nA}$, and a beam diameter of $5 \mu \mathrm{m}$ for glass and $1 \mu \mathrm{m}$ for mineral analyses.

\subsection{Mineralogy: XRD}

Three samples of "restingolites" were crushed to mm-sized chips and separated from the enclosing lava by hand-picking the pumice chips for pristine appearance. The clean chips were then powdered using an agate mill at CEMPEG, Uppsala University. The mineral assemblage of the samples was subsequently determined by X-ray Diffraction (XRD), using a Siemens/Bruker D5000 diffractometer at the Geological Survey of Sweden (SGU) in Uppsala.

\subsection{Major and trace elements: XRF and LA-ICP-MS}

The major and trace element composition of four representative samples were determined by X-ray Fluorescence (XRF) and laser ablation inductively coupled plasma mass spectrometry (LA-ICPMS) at the University of Bremen, Germany. For XRF analyses, hand-picked pumice chips were cleaned in an ultrasonic bath and pulverized in an agate mill. Loss on ignition at $1000^{\circ} \mathrm{C}$ was determined gravimetrically. About $3 \mathrm{~g}$ of powder was mixed with wax, pressed into a pellet and analysed using a Philips PW1400. The LA-ICPMS analyses were carried out on clean pumice chips using a NewWave UP193ss laser coupled to a Thermo Element2. Analytical conditions included a laser beam diameter of $75 \mu \mathrm{m}$, a pulse rate of $5 \mathrm{~Hz}$, an irradiance of ca. $1 \mathrm{GW} \mathrm{cm}^{-2}$, and $0.661 \mathrm{~min}^{-1} \mathrm{He}$ as a sample gas. NIST612 glass was used for quantification with $\mathrm{Ca}$ as the internal standard element; data quality was monitored by analysing BHVO-2G glass. 


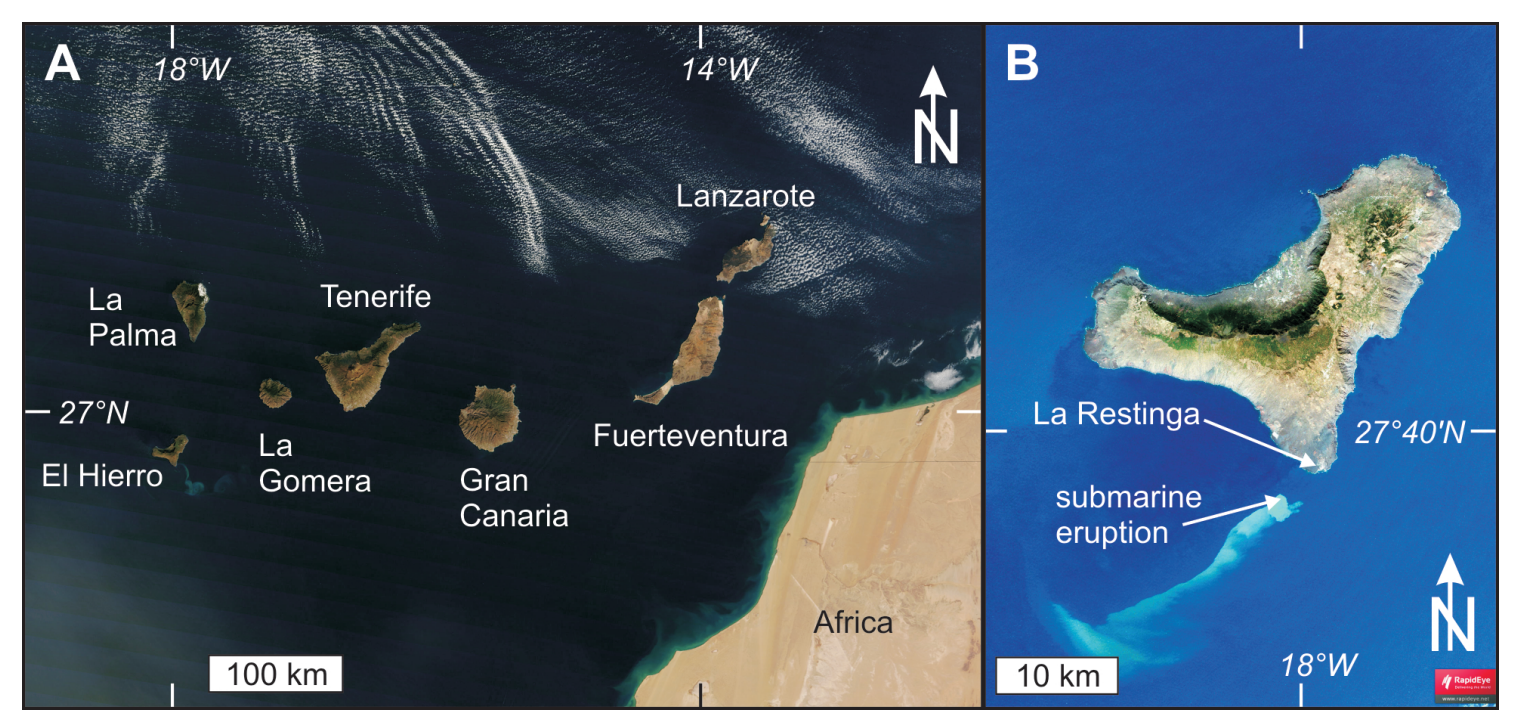

Fig. 1. Satellite images of (A) the Canary Islands west off the coast of Africa. True colour image captured by the Moderate Resolution Imaging Spectroradiometer (MODIS) aboard the Terra satellite on 21 December 2011. The stain of the ocean caused by the submarine eruption can be seen SSE of El Hierro. Image credit: Jeff Schmaltz MODIS Land Rapid Response Team, NASA GSFC. (B) True color RapidEye satellite image of El Hierro and the discolouration of sea water caused by the submarine eruption on 13 October 2011. Image credit: Rapid Eye.

\subsection{Oxygen isotope analysis}

Three samples of "restingolite" were analysed for oxygen isotope ratios using a Thermo Delta XP mass spectrometer at the University of Cape Town (UCT), South Africa. Results are reported in standard $\delta$-notation, [ $\delta=\left(R_{\text {sample }} / R_{\text {standard }}-\right.$ $1) \times 1000$, and $\left.R={ }^{18} \mathrm{O} /{ }^{16} \mathrm{O}\right]$. About $10 \mathrm{mg}$ of powder was dried from each sample in an oven at $50^{\circ} \mathrm{C}$ and degassed under vacuum on a conventional silicate line at $200^{\circ} \mathrm{C}$. Silicates were reacted with $\mathrm{ClF}_{3}$. The liberated $\mathrm{O}_{2}$ was converted to $\mathrm{CO}_{2}$ using a hot platinised carbon rod. Full procedure details are given in Vennemann and Smith (1990) and Harris et al. (1990). Samples were run on the vacuum line along with duplicate samples of the internal quartz standard MQ. All values are given relative to standard mean ocean water (SMOW), and the analytical error is estimated to be $\pm 0.1 \%$ o $(1 \sigma)$, which is based on the long term-duplication of the MQ standard.

\section{Results}

\subsection{Textural observations}

The cores of the "restingolites", i.e. the early floating stones erupted offshore El Hierro during the initial phase of eruption, stand in sharp contrast to their glassy, basanitic crusts (Fig. 2). The cores range in colour from white and cream to medium and dark grey and exhibit a foam- (or pumice-) like texture (Fig. 3) and a glassy matrix. This results in extremely low densities that enable them to float on water, in spite of carrying a dense basanitic crust. Individual vesicles may be several $\mathrm{mm}$ in size, but typically they are on the sub-mm level (Fig. 4). The vesicles are heterogeneously distributed throughout the rock, occurring in bands, individually or as clusters (e.g. Figs. 2-4). In particular, some of the samples show physical mingling textures with the basanitic magma expressed as flow folds and schlieren structures (e.g. Fig. 2e, $\mathrm{f}$ and Fig. 3e). Layering, identified as primary by changes in colour, is frequently folded too and indicates an intense ductile deformation episode (e.g. Fig. 2d-f).

\subsection{Mineral and glass phases}

Most samples of "restingolites" are macroscopically crystalfree and glassy; however, occasional quartz crystals, jasper fragments, gypsum-, calcite-, and clay-aggregates, and wollastonite (former carbonate) have been identified in hand specimens and under the microscope (Fig. 3a-c). X-ray diffractograms indicate the presence of principally quartz, mica and/or illite, smectite, halite, and glass. The occurrence of halite documents the influence of sea water. There is a notable absence of primary igneous minerals (i.e. olivine, pyroxene, feldspar, amphibole) from the XRD data (Table 1). A comparatively significant phyllosilicate peak at ca. $10^{\circ}$ (2Theta), likely reflects the thermal decomposition of smectite to illite (Appendix Figs. A2, A3).

Scanning Electron Microscopy and Energy-Dispersive Xray (EDX) analysis confirms the largely glassy and pervasively vesicular nature of the samples (Fig. 4; Table 2). Microscopic quartz crystals have also been identified and analysed by FE-EPMA (Fig. 4c; Table 2). 
Table 1. Minerals present in "restingolite" samples from XRD analysis. For representative analytical spectra see Appendix Figs. A2 and A3.

\begin{tabular}{cccccccccc}
\hline Sample & Olivine & Pyroxene & Amphibole & Feldspar & Mica & Quartz & Illite & Halite & Smectite \\
\hline EH-XP-1 & x & x & x & x & $\checkmark$ & $\checkmark$ & $\checkmark$ & x & $\checkmark$ \\
EH-XP-2 & x & x & x & x & $\checkmark$ & $\checkmark$ & $\checkmark$ & $\checkmark$ & $\checkmark$ \\
EH-XP-3 & x & x & x & x & $\checkmark$ & $\checkmark$ & $\checkmark$ & x & x \\
\hline
\end{tabular}

$\mathrm{x}=$ not detected, $\checkmark=$ presence confirmed

Table 2. Representative EDX analysis of El Hierro "restingolite" glasses.

\begin{tabular}{lcccccccc}
\hline Sample I.D.: & EH-XP3 & EH-XP4 & EH-XP5 & EH-XP9 & EH-XP11 & EH-XP11 & EH-XP312 & EH-XP13 \\
\hline $\mathrm{SiO}_{2}$ & 73.86 & 74.62 & 74.58 & 75.75 & 71.99 & 63.34 & 89.43 & 100 \\
$\mathrm{Al}_{2} \mathrm{O}_{3}$ & 16.39 & 17.53 & 17.33 & 17.41 & 18.03 & 18.01 & 6.87 & - \\
$\mathrm{Fe}_{2} \mathrm{O}_{3}$ & - & - & - & - & - & - & - & - \\
$\mathrm{MgO}$ & - & - & - & - & - & - & - & - \\
$\mathrm{CaO}$ & 2.06 & - & - & - & - & - & - & - \\
$\mathrm{Na}_{2} \mathrm{O}$ & 1.45 & 2.37 & 3.83 & 2.39 & 4.77 & 11.66 & 1.61 & \\
$\mathrm{~K}_{2} \mathrm{O}$ & 6.24 & 5.47 & 4.26 & 4.44 & 5.21 & 7 & 2.09 & - \\
$\mathrm{SO}_{3}$ & - & - & - & - & - & - & - & - \\
\hline
\end{tabular}

Major elements are given as wt. \% oxide.

\subsection{Major and trace element composition}

The major element composition of glass and crystal phases in the "restingolites" obtained by EDX is given in Table 2. Major and trace element data obtained by XRF on three representative samples are presented in Table 3. For comparison, the following data are also shown in Fig. 5 and Table 3: (i) siliciclastic crustal xenoliths from Gran Canaria and Lanzarote (Hansteen and Troll, 2003; Aparicio et al., 2006), (ii) ocean floor dredged sediment from off El Hierro (Berg, 2011), (iii) basanites and trachytes from El Hierro (Pellicer, 1979, Carracedo et al., 2001), (iv) trachytes and rhyolites from Gran Canaria (Troll and Schmincke, 2002), and (v) phonolites from Tenerife (Rodriguez-Badiola et al., 2006).

The composition of glass in the early El Hierro "restingolites" is dominated by $\mathrm{SiO}_{2}$ (70 to $80 \mathrm{wt}$. \%) (Tables 2 and 3 ). In fact, the glassy coating on the restite in Fig. 4c contains 89 wt. $\% \mathrm{SiO}_{2}$, while the crystal in the centre of this image yields 100 wt. $\% \mathrm{SiO}_{2}$ (i.e. it is quartz). Aside from silica, other major constituents are $\mathrm{Al}_{2} \mathrm{O}_{3}$ (up to 18 wt. \%), $\mathrm{Na}_{2} \mathrm{O}$ (up to 6 wt. \%), and $\mathrm{K}_{2} \mathrm{O}$ (about 5 wt. \%), while $\mathrm{FeO}$ and $\mathrm{CaO}$ contents are very low (Tables 2 and 3 ). The concentration of some trace elements is also remarkably low (e.g. Zr; Table 3; Fig. 5), especially given their high $\mathrm{SiO}_{2}$ content. Additionally, the rare earth element (REE) concentrations are severely depleted (by half) of what is typical for highly differentiated Canary Island magmatic rocks. In fact, the REE content of the "restingolites" is as low as that of many mafic magmas in the Canaries. This discrepancy of high-silica major element and mafic-like trace element signatures underlines that the "restingolites" are atypical for Canary, and probably any other, magmatic compositions. Chemically, they rather resemble known sedimentary xenoliths and pre-island sedimentary compositions.

\subsection{Oxygen isotope composition}

Oxygen isotope data has been obtained on three "restingolite" samples, yielding $\delta^{18} \mathrm{O}$ values of 9.1, 11.0, and $11.6 \%$. These values are elevated relative to known magmatic samples reported from the Canary Archipelago, including highly evolved magmas, such as trachyte and rhyolite from Gran Canaria with $\delta^{18} \mathrm{O}$ values of 6.4-7.4\%o (Troll and Schmincke, 2002; Hansteen and Troll, 2003). For comparison, quartz-rich sedimentary xenoliths found on Gran Canaria, which are texturally and chemically analogous to the early floating stones off El Hierro, display a range of $\delta^{18} \mathrm{O}$ values between 14.1 to $16.4 \%$ (Hansteen and Troll, 2003).

\section{Similar rocks from elsewhere in the Canary Islands}

Eruption products similar to the early samples from El Hierro are known from historic and Holocene volcanic activity on the Canary Archipelago. Araña and Ibarolla (1973) report "rhyolitic pumice" erupted during the 1971 eruption of Teneguía on La Palma that is of similar texture and composition and thus likely of similar origin to our samples. Xenoliths of similar nature were also found in the 1949 eruptions on La Palma (Klügel et al., 1999) and in 
Table 3. Whole-rock major and trace element composition of El Hierro "restingolites" and Gran Canaria and Lanzarote crustal xenoliths, El Hierro flank sediment, and representative Canary Island magmatic rocks for comparison.

\begin{tabular}{|c|c|c|c|c|c|c|c|c|c|c|}
\hline \multirow[b]{2}{*}{ Sample I.D.: } & \multicolumn{3}{|c|}{ El Hierro early floating stones ("restingolites") } & \multicolumn{2}{|c|}{ Canary Crustal Xenoliths } & \multirow{2}{*}{$\begin{array}{l}\text { EH-Flank Sediment } \\
\text { SED174-1-1 }\end{array}$} & \multicolumn{4}{|c|}{ Representative Canary Igneous Rocks } \\
\hline & $\mathrm{H} 12110^{1}$ & $\mathrm{EH} 2510-1^{2}$ & $\mathrm{EH} 2110-2^{3}$ & HAT917C 4 & ANG- $58^{5}$ & & $\mathrm{C} 1 \mathrm{H} 102^{7}$ & $\mathrm{EH} 21^{8}$ & $\mathrm{AI}-\mathrm{MCa}^{9}$ & $\mathrm{CAB}^{10}$ \\
\hline $\mathrm{SiO}_{2}$ & 69.19 & 71.03 & 68.61 & 86.7 & 83.48 & 32.35 & 56.43 & 59.96 & 69.27 & 60.88 \\
\hline $\mathrm{TiO}_{2}$ & 0.22 & 0.18 & 0.21 & 0.4 & 0.36 & 3.44 & 1.26 & 0.91 & 0.68 & 0.70 \\
\hline $\mathrm{Al}_{2} \mathrm{O}_{3}$ & 15.76 & 15.10 & 15.43 & 4.9 & 7.05 & 11.61 & 19.30 & 19.38 & 14.47 & 19.42 \\
\hline $\mathrm{Fe}_{2} \mathrm{O}_{3}$ & 0.73 & 0.69 & 0.71 & 2.5 & 2.35 & 12.29 & 5.60 & 4.11 & 3.56 & 3.30 \\
\hline $\mathrm{MnO}$ & 0.01 & 0.02 & 0.02 & 0.06 & 0.05 & 0.21 & 0.28 & 0.24 & 0.15 & 0.16 \\
\hline $\mathrm{MgO}$ & 0.31 & 0.12 & 0.55 & 1.3 & 2.25 & 9.98 & 1.33 & 0.85 & 0.29 & 0.41 \\
\hline $\mathrm{CaO}$ & 0.48 & 0.31 & 0.47 & 1.2 & 1.31 & 5.95 & 5.73 & 4.30 & 0.36 & 0.97 \\
\hline $\mathrm{Na}_{2} \mathrm{O}$ & 6.09 & 6.11 & 6.52 & 0.8 & 0.76 & 2.61 & 7.23 & 7.14 & 6.58 & 8.37 \\
\hline $\mathrm{K}_{2} \mathrm{O}$ & 4.88 & 4.73 & 4.78 & 0.9 & 1.5 & 0.92 & 2.43 & 2.90 & 4.39 & 5.46 \\
\hline $\mathrm{P}_{2} \mathrm{O}_{5}$ & 0.07 & 0.04 & 0.05 & 0.06 & 0.09 & 0.94 & 0.41 & 0.19 & 0.06 & 0.10 \\
\hline LOI & 1.19 & 1.06 & 1.00 & 1.57 & 0.6 & 19.3 & - & - & - & 0.31 \\
\hline Sum & 98.93 & 99.39 & 98.35 & 100.38 & 99.80 & 99.74 & 100.00 & 100.00 & 99.81 & 100.08 \\
\hline $\mathrm{Cl}$ & 7660 & 4160 & 13342 & - & - & - & - & - & - & - \\
\hline $\mathrm{Ba}$ & 436. & 543. & 496 & 131 & 330 & 114 & 801 & 868 & 693 & 527 \\
\hline $\mathrm{Co}$ & 1.10 & 1.02 & 0.63 & - & 5.29 & 49 & 4 & 37 & $<4$ & 0.6 \\
\hline $\mathrm{Cr}$ & 5.65 & 0.52 & 1.11 & - & 62.9 & 166 & 2 & 9 & $<18$ & 5.5 \\
\hline $\mathrm{Cu}$ & 9.71 & 2.61 & 6.43 & 65.1 & 10.2 & 104 & - & - & - & $<3$ \\
\hline $\mathrm{Nb}$ & 72.51 & 56.21 & 56.05 & 6.5 & 6.78 & 78 & 172 & 214 & 148 & 185 \\
\hline $\mathrm{Ni}$ & 2.08 & 1.66 & 10.30 & - & 25.6 & 91 & 6 & - & - & $<4$ \\
\hline $\mathrm{Pb}$ & 7.26 & 14.25 & 7.14 & 3.89 & - & 5.69 & - & 4 & 7 & 17.6 \\
\hline $\mathrm{Rb}$ & 42.98 & 49.34 & 48.29 & 31.7 & 56.8 & 1.8 & 68.4 & 93 & 100 & 151 \\
\hline $\mathrm{Sr}$ & 90.44 & 79.39 & 135.03 & 113 & 127 & 444 & 2099 & 1465 & 30 & 34.2 \\
\hline Th & 5.53 & 7.58 & 6.93 & 3.62 & - & 3.5 & 15 & 23 & 19 & 26.2 \\
\hline $\mathrm{U}$ & 23.90 & 11.80 & 3.28 & 0.52 & - & 1.2 & - & - & - & 6.89 \\
\hline V & 0.99 & 0.47 & 1.51 & - & 57.5 & 193 & 34.6 & 37 & 31 & 11.7 \\
\hline $\mathrm{Zn}$ & 21.54 & 37.40 & 38.01 & 28.4 & 36.0 & 142 & 186 & 149 & 159 & 101 \\
\hline $\mathrm{Zr}$ & 237 & 220 & 212 & 25.6 & 98.2 & 310 & 857 & 1191 & 1037 & 960 \\
\hline $\mathrm{Rb} / \mathrm{Sr}$ & 0.48 & 0.62 & 0.36 & 0.28 & 0.45 & 0.00 & 0.03 & 0.06 & 3.33 & 4.42 \\
\hline $\mathrm{U} / \mathrm{Th}$ & 4.32 & 1.56 & 0.47 & 0.14 & - & 0.34 & - & - & - & 0.26 \\
\hline $\mathrm{Zr} / \mathrm{Nb}$ & 3.27 & 3.91 & 3.77 & 3.94 & 14.44 & 3.97 & 4.98 & 5.56 & 7.01 & 5.19 \\
\hline $\mathrm{Y}$ & 9.98 & 5.78 & 4.67 & 8.57 & 13.7 & 32 & 58.5 & 53 & - & 26.3 \\
\hline $\mathrm{La}$ & 29.23 & 28.84 & 34.57 & 14 & 14.5 & 43.9 & 151 & 149 & 93 & 91.6 \\
\hline $\mathrm{Ce}$ & 77.76 & 62.95 & 85.16 & 28 & 29.72 & 98.66 & 305 & 302 & $397>$ & 153 \\
\hline $\operatorname{Pr}$ & 7.19 & 7.55 & 7.99 & 3.23 & 3.61 & 11.7 & 36.23 & 30 & - & 14.4 \\
\hline $\mathrm{Nd}$ & 23.85 & 21.26 & 25.52 & 12 & 13.87 & 50.1 & - & - & - & 44.1 \\
\hline $\mathrm{Sm}$ & 4.14 & 4.74 & 4.15 & 2.49 & 2.76 & 8.4 & - & - & - & 6.75 \\
\hline $\mathrm{Eu}$ & 0.76 & 0.80 & 0.82 & 0.53 & 0.64 & 2.4 & - & - & - & 1.68 \\
\hline $\mathrm{Gd}$ & 2.63 & 2.38 & 2.49 & 2.26 & 2.47 & 7.0 & - & - & - & 5.1 \\
\hline $\mathrm{Tb}$ & 0.39 & 0.30 & 0.30 & 0.31 & 0.365 & 0.9 & - & - & - & 0.82 \\
\hline Dy & 2.13 & 1.57 & 1.56 & 1.61 & 2.248 & 5.6 & - & - & - & 4.75 \\
\hline Ho & 0.37 & 0.27 & 0.22 & 0.28 & 0.507 & 1.0 & - & - & - & 0.90 \\
\hline $\mathrm{Er}$ & 0.97 & 0.62 & 0.52 & 0.78 & 1.3 & 2.1 & - & - & - & 2.64 \\
\hline $\mathrm{Tm}$ & 0.18 & 0.09 & 0.09 & 0.11 & 0.212 & 0.3 & - & - & - & 0.41 \\
\hline $\mathrm{Yb}$ & 1.15 & 0.60 & 0.65 & 0.64 & 1.441 & 1.8 & - & - & - & 2.91 \\
\hline $\mathrm{Lu}$ & 0.17 & 0.08 & 0.09 & 0.09 & 0.26 & 0.3 & - & - & - & 0.45 \\
\hline Hf & 5.83 & 6.84 & 7.24 & 0.66 & - & 5.81 & - & - & - & 16.4 \\
\hline $\mathrm{Ta}$ & 3.93 & 4.81 & 4.79 & 0.53 & - & 3.9 & - & - & - & 12.4 \\
\hline
\end{tabular}

Major elements are given as wt. \% oxide; trace elements are given in ppm; "-" indicates that no data is available.

Notes: ${ }^{1-3}$ Samples of "restingolites" collected off-shore El Hierro, October 2011. Major elements analysed by XRF; trace elements by LA-ICP-MS at the University of Bremen,

Germany.

${ }^{4}$ HAT917C is a siliclastic sedimentary xenolith from Gran Canaria (Hoernle, 1998; Hansteen and Troll, 2003).

5 ANG-58 is a siliclastic sedimentary xenolith from Lanzarote (Aparicio et al., 2006).

6 SED 174-1-1 is an El Hierro submarine flank sediment (Berg, 2011).

7 Trachytes from El Hierro (Carracedo et al., 2001)

${ }^{8}$ Contaminated trachytic rind material of restingolite from El Hierro. Data obtained by XRF at the University of Bremen, Germany.

${ }^{9} \mathrm{~A} 1-\mathrm{MCa}$ is a rhyolite from Gran Canaria (Troll and Schminke, 2002).

${ }^{10} \mathrm{CAB}$ is a phonolite from Tenerife (Wiesmaier, 2010). 


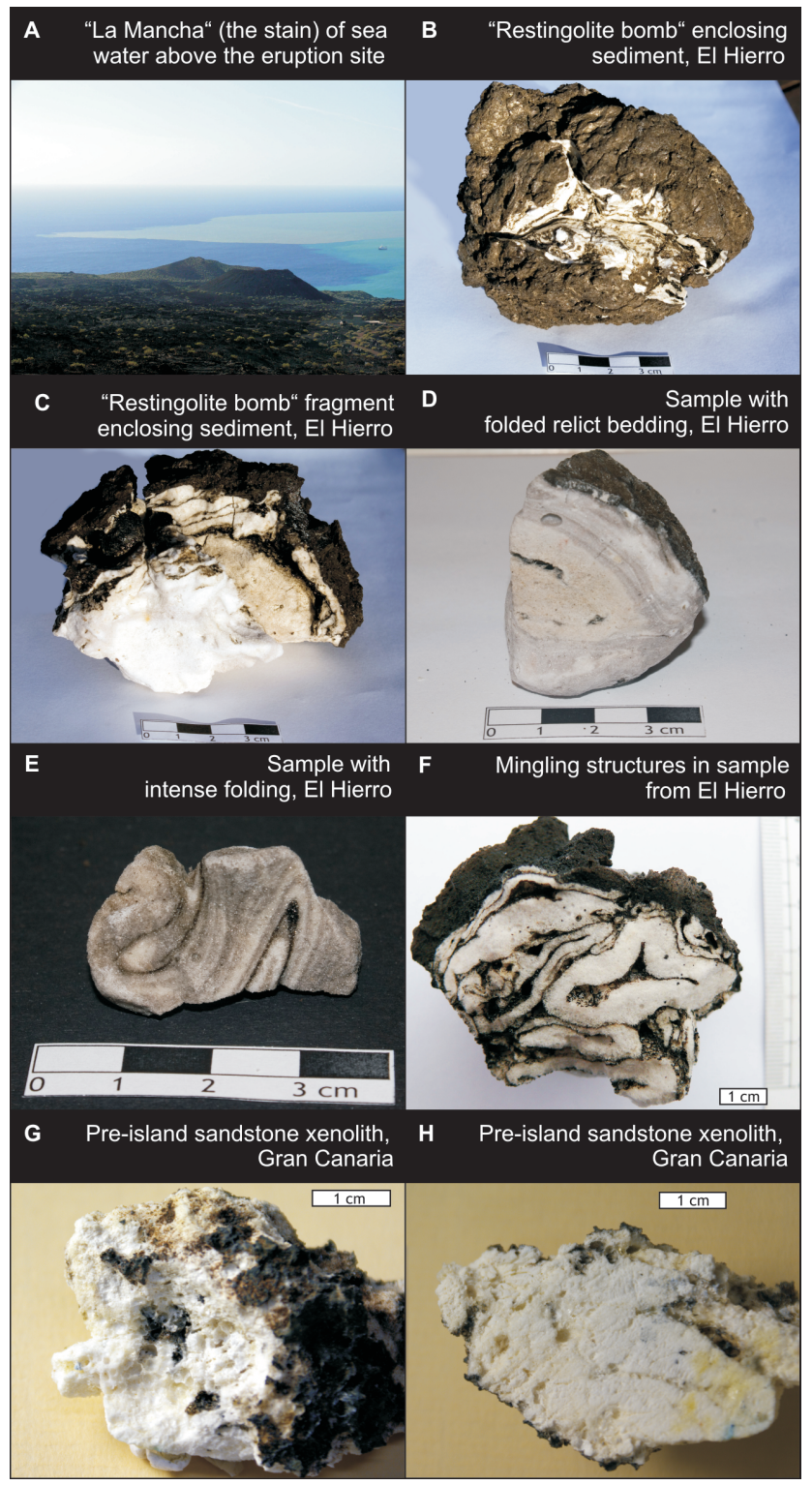

Fig. 2. Overview of features of "restingolites" from El Hierro. (A) Ocean surface above the offshore eruption. Note the changed colour of the water (locally referred to as "la mancha", i.e. "the stain") that occurred early during the eruption. (B-F) Samples displaying typical textural features, such as a crust of basanite, primary sedimentary bedding, folded bedding and schlieren, high vesicularity, and mingling structures. (G and H) "Xeno-pumice" samples from Gran Canaria that resemble El Hierro "restingolites" and which have been demonstrated to originate from pre-island sandstone layers. For additional sample images see Appendix Fig. A1.

eruption products of the submarine volcanic edifice Hijo de Tenerife offshore between Gran Canaria and Tenerife (Schmincke and Graf, 2000). Furthermore, partly melted sandstone xenoliths were found in Holocene basanite eruptives of Gran Canaria (Hansteen and Troll, 2003) and Aparicio et al. $(2006,2010)$ describe similar xenoliths, some including fossil-bearing limestone and shale from the lavas of
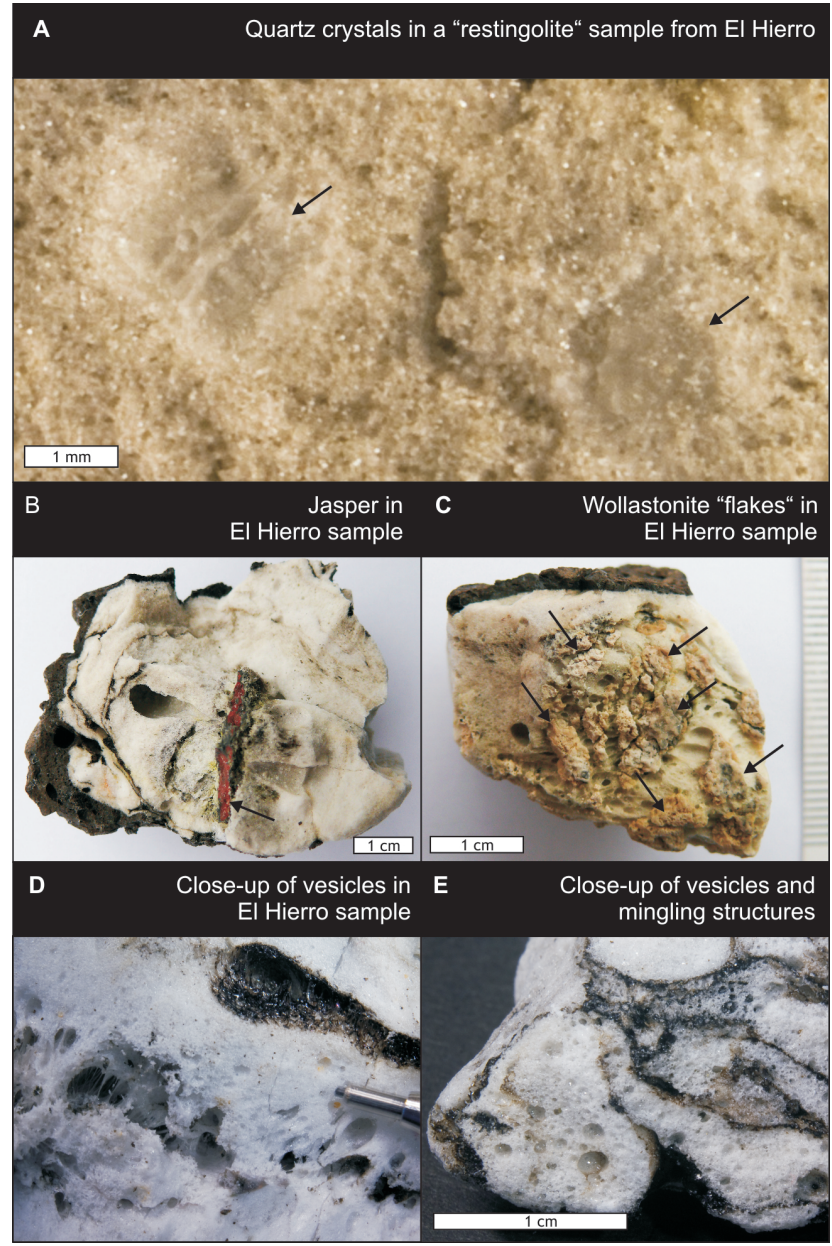

Fig. 3. Overview of small-scale features of early floating stones ("restingolites") from El Hierro. (A) mm-size quartz crystals. (B) Jasper inclusions (C) Wollastonite "flakes". (D and E) Vesicles and mingling textures.

the 1730-1736 Timanfaya eruption on Lanzarote. Moreover, uplifted pre-island sedimentary rocks in the Basal complex of Fuerteventura are also quartz-rich, and are interlayered with clays and minor carbonates (cf. Stillman et al., 1975).

We have analysed samples of such xenoliths from Gran Canaria, La Palma, and Lanzarote that have undergone heating, degassing, and expansion. In particular, a suite of samples of white, vesicular sandstone xenoliths from Gran Canaria strikingly resemble the early El Hierro floating stones in texture, composition and general appearance (cf. Hoernle, 1998; Hansteen and Troll, 2003; Berg, 2011). The Gran Canaria sandstone samples are glassy, strongly vesicular (Fig. $2 \mathrm{~g}$ and h; Fig. 4g-i), and contain variable amounts of rounded and partly resorbed quartz crystals. Xenopumice from Gran Canaria exhibits density values as low as $0.54 \mathrm{~g} \mathrm{~cm}^{-3}$ and open porosity values of up to $78 \%$. Xray $\mu$-CT imaging reveals vesicle networks and pipelines through which gas has left the xenoliths (see Appendix for method details). 

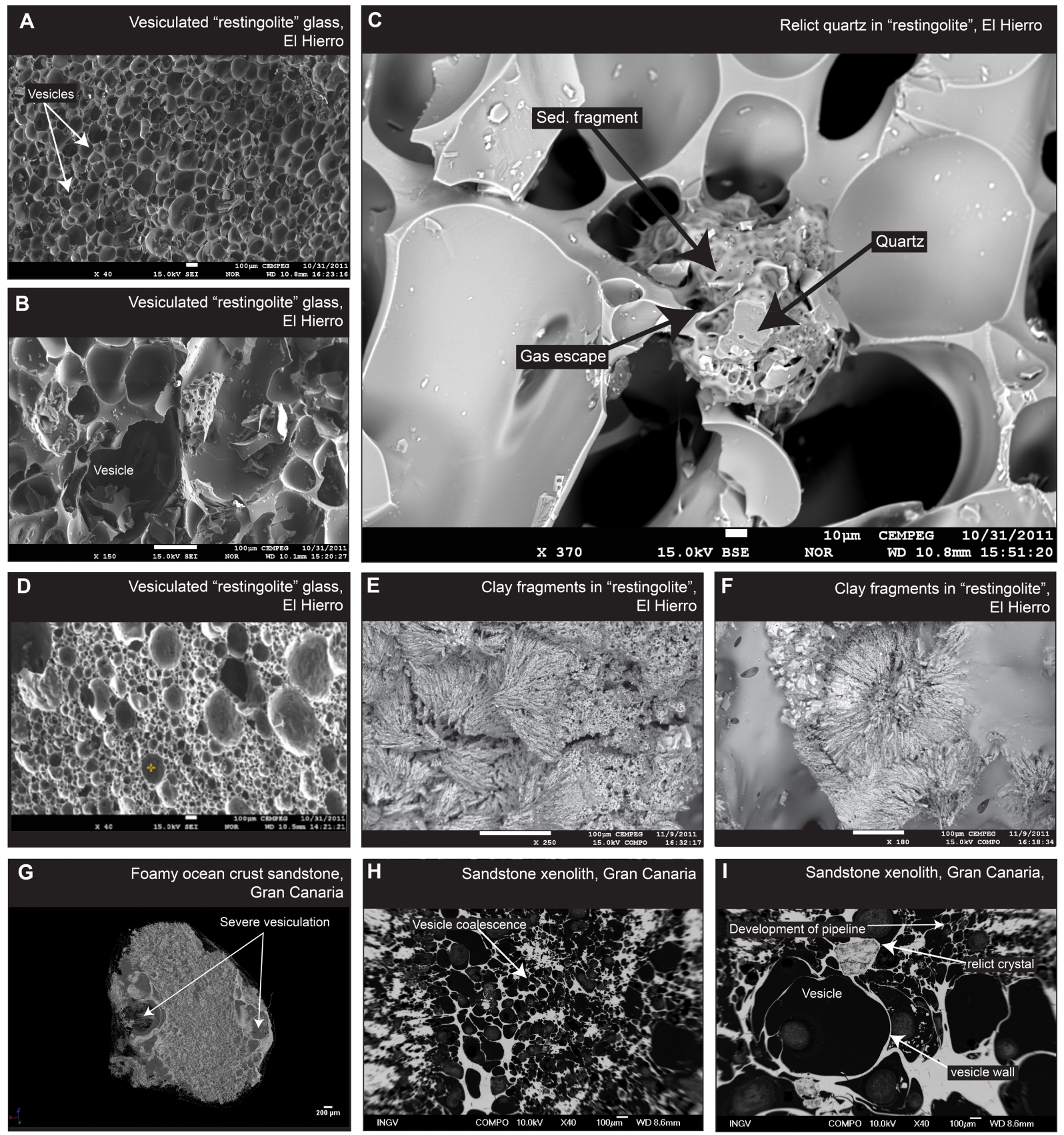

Fig. 4. SEM images of "restingolites" (A-F) and comparative images of Gran Canaria ocean crust sediment xenoliths (G-I). (A) Pervasive micro-vesicularity in early El Hierro floating stones. (B) and (D) Details of vesicle distribution and vesicle wall textures. (C) High resolution image of sedimentary fragment in early El Hierro floating stone that has not yet fully melted. The melt surrounding the fragment has $\mathrm{SiO}_{2}$ of $89 \%$ and a several-tens-of-microns large quartz crystal is seen in the centre of the image (compare Table 2). (E) and (F) Remnants of clay aggregates found in early El Hierro floating stones. Note in F these relicts are surrounded by glass. (G) Synchrotron X-ray computed micro-tomography image of a vesicular sedimentary xenolith from Gran Canaria, showing textures and compositions similar to the early El Hierro floating stones (compare Table 3). (H) and (I) SEM images of vesicular sedimentary xenoliths from Gran Canaria with relict quartz crystals and thin vesicle walls, i.e. they display textures very similar to the El Hierro "restingolite" suite. 

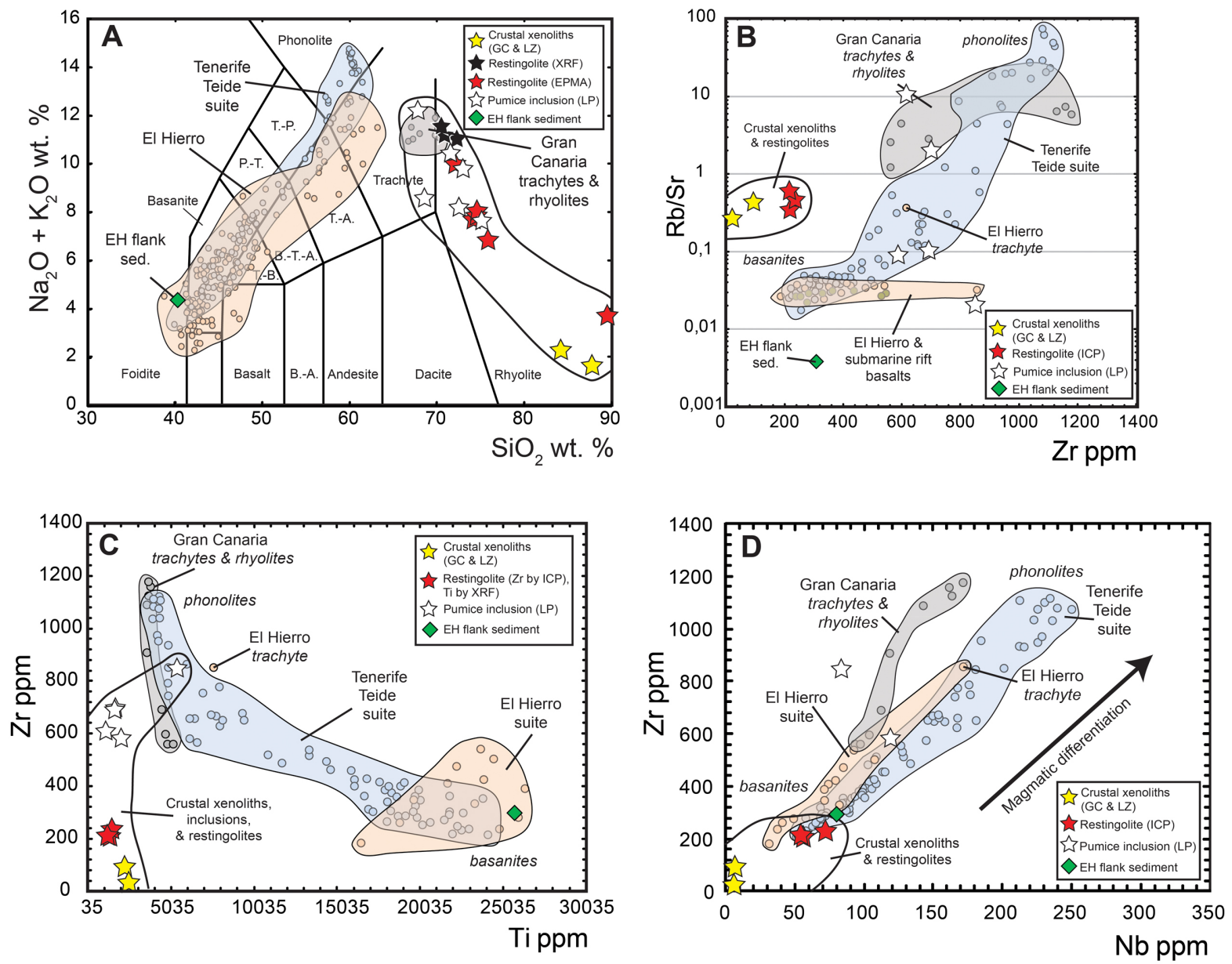

Fig. 5. Geochemical plots of early El Hierro floating stones ("restingolites") and comparative data for magmatic rocks from El Hierro, Gran Canaria, and Tenerife, and Canary Island crustal xenoliths. (A) Total alkalis versus silica (TAS) plot showing the alkaline Canary Island magma suites. The early El Hierro floating stones plot within the trachyte to rhyolite fields, however, they do not follow a typical Canary Island magmatic trend. Note that known crustal xenoliths from Gran Canaria (Hansteen and Troll, 2003) and Lanzarote (Aparicio et al., 2006) and probable xeno-pumice inclusions from La Palma (Arana and Ibarrola, 1971; Klügel et al., 1999) also plot as rhyolites. (B) Rb/Sr versus $\mathrm{Zr}$ plot. The most evolved Canary Island magmas plot to the top right of the diagram. The "restingolites" and crustal xenoliths form a distinct group from both, the least and most evolved magmatic samples. La Palma xeno-pumice inclusions show a large degree of scatter, and do not follow any distinct magmatic trend. (C) Zr versus $\mathrm{Ti}$ (ppm) plot, showing the main Canary magmatic trends (Tenerife, El Hierro and Gran Canaria) and the composition of the crustal xenoliths and the early El Hierro floating stones. Note that the magmatic samples on the one side form a distinctly different trend to that of the crustal compositions from Gran Canaria, Lanzarote, La Palma, and the early El Hierro "restingolites" on the other. (D) Zr versus Nb plot. Canary Island igneous suites show strong magmatic differentiation trends, with the most evolved samples plotting to the top right of the diagram (i.e. at high $\mathrm{Zr}$ and $\mathrm{Nb}$ concentrations). In contrast to the TAS plot, early El Hierro floating stones plot near the least evolved magmatic samples. The chemical data thus underline that early El Hierro floating stones are highly atypical for Canary magma compositions and chemically resemble known sedimentary xenolith and pre-island sedimentary compositions once the full major and trace element compositions are considered. Reference data fields El Hierro (Pellicer, 1979; Carracedo et al., 2001), Gran Canaria (Hoernle, 1998; Troll and Schmincke, 2002), Tenerife (Rodriguez Badrola et al., 2006; Wiesmaier, 2010). Abbreviations: GC, Gran Canaria; LZ, Lanzarote; LP, La Palma. 


\section{Discussion: nature and origin of the "restingolites"}

The high silica content coupled with overall low incompatible trace element concentrations, the occurrence of mm-sized relict quartz crystals, and the lack of igneous minerals, plus the occurrence of wollastonite, clay, jasper, calcite, and gypsum relicts are all incompatible with a purely igneous origin for the cores of the early El Hierro floating stones (cf. Table 1). In fact, El Hierro igneous rocks are generally silicaundersaturated, and the most evolved igneous rock reported from El Hierro reaches only silica concentrations of $65 \mathrm{wt}$ \% (Pellicer, 1979). Igneous rocks on El Hierro do not contain any free (primary) quartz crystals (nor do igneous rocks on any of the other Canary Islands).

A likely source of the quartz crystals found in the floating rocks from El Hierro are sand plumes that originate from large sand storms in continental Africa, which can transport considerable quantities of aeolian sediment that is deposited in the Canarian Archipelago (e.g. Criado and Dorta, 1999). These wind-blown sediments are very fine-grained, which rules out a purely aeolian transport for the $\mathrm{mm}$-sized quartz crystals found in the early El Hierro floating stones. Instead, the sedimentary rocks of layer 1 of the pre-island ocean crust consist of material transported from Africa by both wind and turbidity currents (cf. Criado and Dorta, 1999; Ye at al., 1999; Gee et al., 1999; Krastel and Schmicke, 2002), and are intermixed with regular oceanic background sedimentation. These pre-volcanic sedimentary rocks of ocean crust layer 1 are thus likely to contain larger quartz crystals and will display a variety of sedimentary facies. The absence of any igneous minerals, such as olivine, pyroxene, amphibole or other accessory phases, such as titanite, chevkinite or zircon (cf. Sumita and Schmincke, 1998; Troll et al., 2003), in the early El Hierro floating stones, coupled with their unusual trace-element chemistry, demonstrates that the rocks are neither derived from a typical evolved Canary magma nor from volcaniclastic sediments on the submarine slopes of El Hierro, as both would contain igneous minerals. In the former case, these minerals would have grown from the magma itself and in the latter they would have been concentrated due to the considerable detrital input of heavy igneous minerals from the island (cf. Sumita and Schmicke, 1998). The virtually complete absence of igneous minerals, in turn, suggests that the sedimentary protolith to the early El Hierro floating stones was formed before any igneous activity affected the sedimentation around El Hierro, i.e. they formed before the island was built, otherwise igneous minerals would still be expected, especially given that relict clays (low melting temperature) are observed in many samples. Layer 1 of the oceanic crust is usually built of deep-sea sediments and, near continents, terrigenous, turbidity-current sediments (cf. Fig. 6). We therefore propose that it is these pre-island sedimentary rocks of ocean crust layer 1 that have been brought up as floating xenoliths. Based on their "frothy" texture, we term these and other vesicular xenoliths

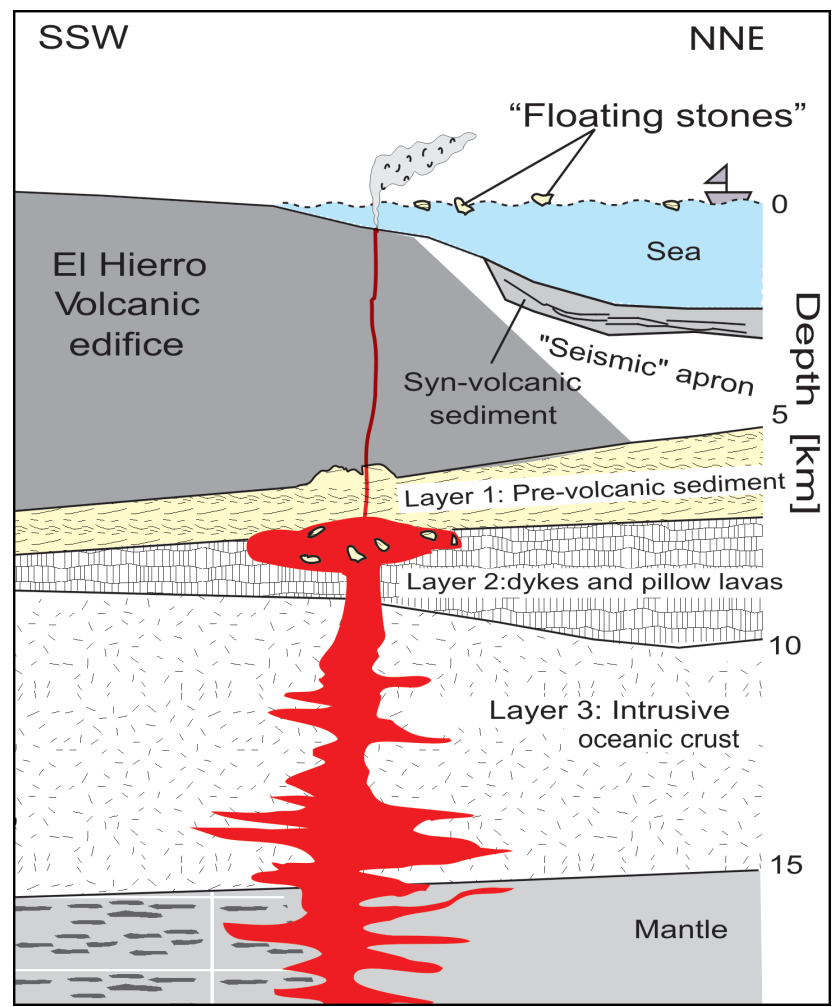

Fig. 6. Sketch showing the internal structure of El Hierro Island. Ascending magma is interacting with the pre-volcanic sedimentary rocks, and we suggest that the early floating stones found at $\mathrm{El} \mathrm{Hi}-$ erro are the products of magma-sediment interaction beneath the volcano. Pre-island sedimentary material was carried to the ocean floor during magma ascent and eruption and melted and vesiculated while immersed in magma to develop a pumice-like texture ("xenopumice"). Once erupted onto the ocean floor, these xeno-pumices separated from the host lava and floated on the sea surface due to their high vesicularity (i.e. their low density).

"xeno-pumice", because they are pumice-like in appearance but xenolithic in origin.

This interpretation is consistent with the currently available oxygen isotope data, which are significantly above regular magmatic (i.e. mantle-derived) compositions and their respective variations due to crystal fractionation (cf. Harris et al., 2000; Troll and Schmincke, 2002). A purely magmatic scenario can result in an increase of about $1 \%$ above a mantle value of ca. $5.7 \pm 0.3 \%$ through closed-system crystal fractionation (Sheppard and Harris, 1985; Harris et al., 2000; Troll and Schmincke, 2002), but cannot explain the observed values of $9.1-11.6 \%$. This is strong evidence that the early El Hierro floating stones are not representative of a magma, but instead have a crustal origin. Sediments can attain extremely high $\delta^{18} \mathrm{O}$ values of $>20 \%$ o, with a wide range of 11.5 to $28.5 \%$ reported in Savin and Epstein (1969). However, as a result of isotopic exchange between sediment and host basanite during transport through the volcano, 
sedimentary xenoliths often show a slightly lower $\delta^{18} \mathrm{O}$ range as might be expected from pristine sediments (see Hansteen and Troll, 2003; Aparicio et al., 2006). The oxygen isotope data, in conjunction with elemental and mineralogical evidence, thus support our argument that the El Hierro floating stones are xeno-pumices that originate from sedimentary units of pre-island ocean crust (see Fig. 6).

The features of the El Hierro xeno-pumice samples described above indicate that they became heated, melted and vesiculated during their transport in magma. The mingling textures and the often sharp contact to the enclosing basanite indicate that these samples came in contact with the magma only shortly prior to eruption (hours), whereas complete assimilation and homogenisation would require a somewhat longer time (cf. McLeod and Sparks, 1998; Perugini et al., 2010). Thermal conductivity values of typical rocks show that a basaltic magma would melt a fist-size sedimentary xenolith in about half an hour (Klügel et al., 1997), a time during which significant mingling of melts may already have occur. It is apparent that this melting and the associated vesiculation of the sedimentary xenoliths leads to a dramatic density decrease, giving them sufficient buoyancy in the magma and in sea water. Vesiculation most probably results from progressive degassing of the xenolith melt caused by the break-down and decomposition of hydrous minerals. This degassing in turn raises the melting temperature and viscosity of the xeno-pumice melt, retarding mixing and mingling and probably causing partial "freezing" of the melt (cf. Sparks and Marshall, 1986; McLeod and Sparks, 1998; Hammer et al., 1999). Both processes (degassing and freezing) have likely contributed to an effective detachment of the xeno-pumices from the erupted lava to rise as "floating stones" during the early phase of the El Hierro eruption.

Beneath El Hierro, the pre-island sedimentary rocks are likely to be less voluminous (and probably more finegrained) than under, e.g. Gran Canaria, and may reside at depths of approximately 5 to $7 \mathrm{~km}$ below sea level (cf. Collier and Watts, 2001; Ye et al., 1999; Fig. 6). Seismicity at El Hierro prior to and in the early phase of the eruption clustered primarily between 7 and $17 \mathrm{~km}$ depth, i.e. within the igneous ocean crust and at the base of crustal layer 1 (IGN, 2011), which is slightly above the proposed main level of crystal fractionation (19-26 km) proposed for El Hierro magmas (e.g. Stroncik et al., 2009). The large quantities of xeno-pumice of El Hierro during the early eruption phase and their disappearance during the later stages of the eruption are likely consequences of the establishment of a relatively stable conduit, the formation of which required clearing the way for the ascending magma through the sedimentary rocks of layer 1 (Fig. 6; also compare IGN, 2011). In contrast, fragments of the oceanic crust layer 2 and 3 (pillow lavas, sheeted dykes, and layered gabbro) would not rise buoyantly to the sea surface due to considerably higher melting points and generally significantly lower volatile contents.

\section{Implications and conclusions}

The early "floating stones" observed in October 2011 off El Hierro, Canary Islands, thus originate from pre-island sedimentary rocks, in particular quartz-rich sand- and mudstones, from layer 1 of the oceanic crust beneath $\mathrm{El} \mathrm{Hi}$ erro. These xenoliths melted and vesiculated during transport in magma resulting in pumice-like appearance ("xenopumice"), and are thus messengers from depth that attest to the importance of magma-crust interaction beneath the $\mathrm{Ca}$ nary Islands. Magma-crust interaction is likely to be most pronounced in young edifices in their main shield-building stage and may also play a role in the volatile budget of the initial phases of such eruptions. The occurrence of high-silica "xeno-pumices" off El Hierro, however, does not indicate the presence of explosive high-silica magma in the current plumbing system beneath El Hierro.

\section{Appendix A}

\section{Synchrotron tomography}

X-ray microtomography imaging was performed at the SYRMEP beamline at the ELETTRA synchrotron light source, Basovizza, Trieste, Italy. We obtained 1440 radiographs of each sample (up to $10 \times 5 \times 5 \mathrm{~mm}$ in size) using a beam energy of between 25 and $48 \mathrm{KeV}$ and a 12 bit water cooled CCD camera with a pixel size of $9 \times 9 \mu \mathrm{m}$ as a detector. The camera field of view was $18 \times 12 \mathrm{~mm}$. Slice reconstruction was performed using the filter back projection method and we produced volume renderings with VGStudio Max 2.0 ${ }^{\circledR}$ 3-D software. Reconstructed volumes were then analysed using the Pore 3-D software library (Brun et al., 2010). For additional details about this method see Polacci et al. (2010). 


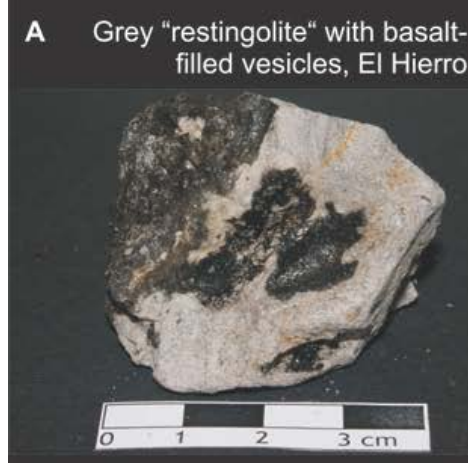

C Mingling structures in "restingolite" sample from El Hierro

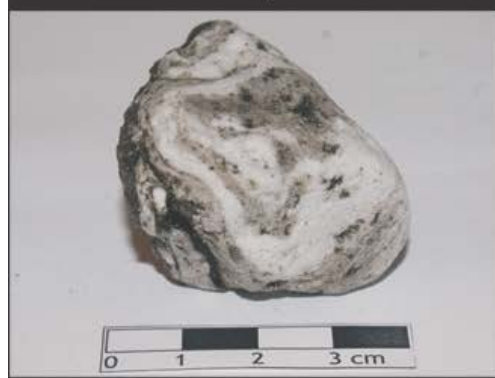

E

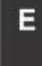

" sample,
B
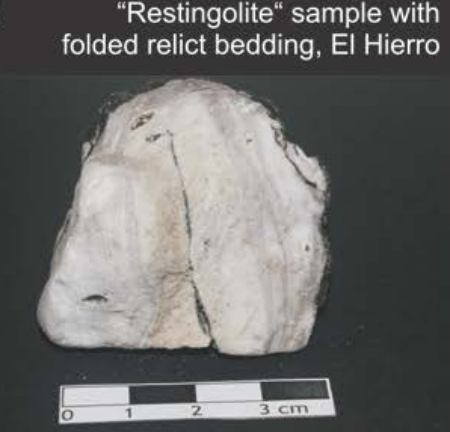

D

Vesiculated and folded "restingolite" from El Hierro

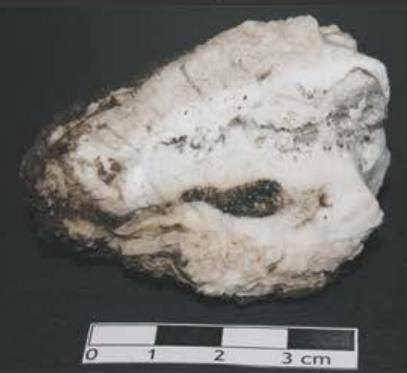

"Restingolite" sample with folded relict bedding, El Hierro

$\mathbf{F}$
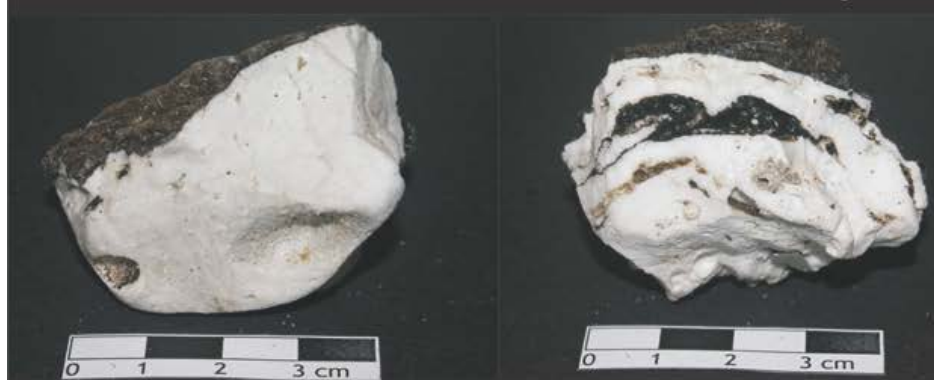

Close-up of vesicles

G

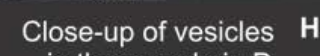

H in the sample in $\mathrm{E}$

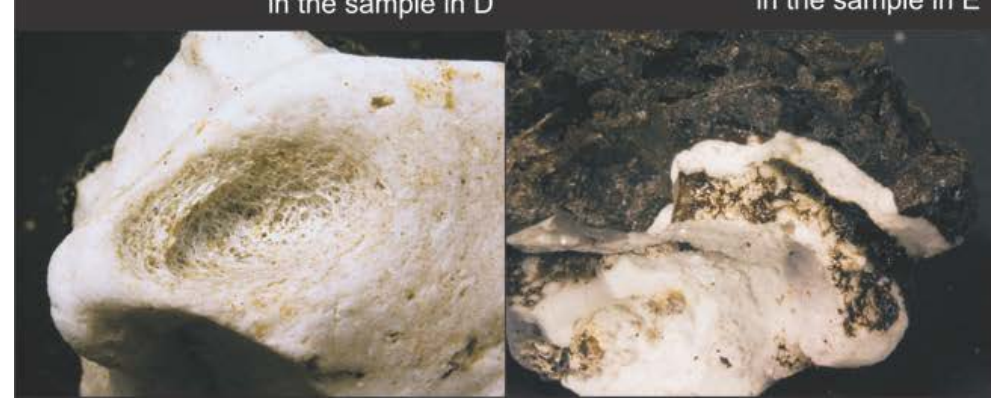

Fig. A1. Images of "restingolite" samples from El Hierro, displaying typical features, such as a rind of basanite, layering, folding, vesicularity, and mingling structures. 


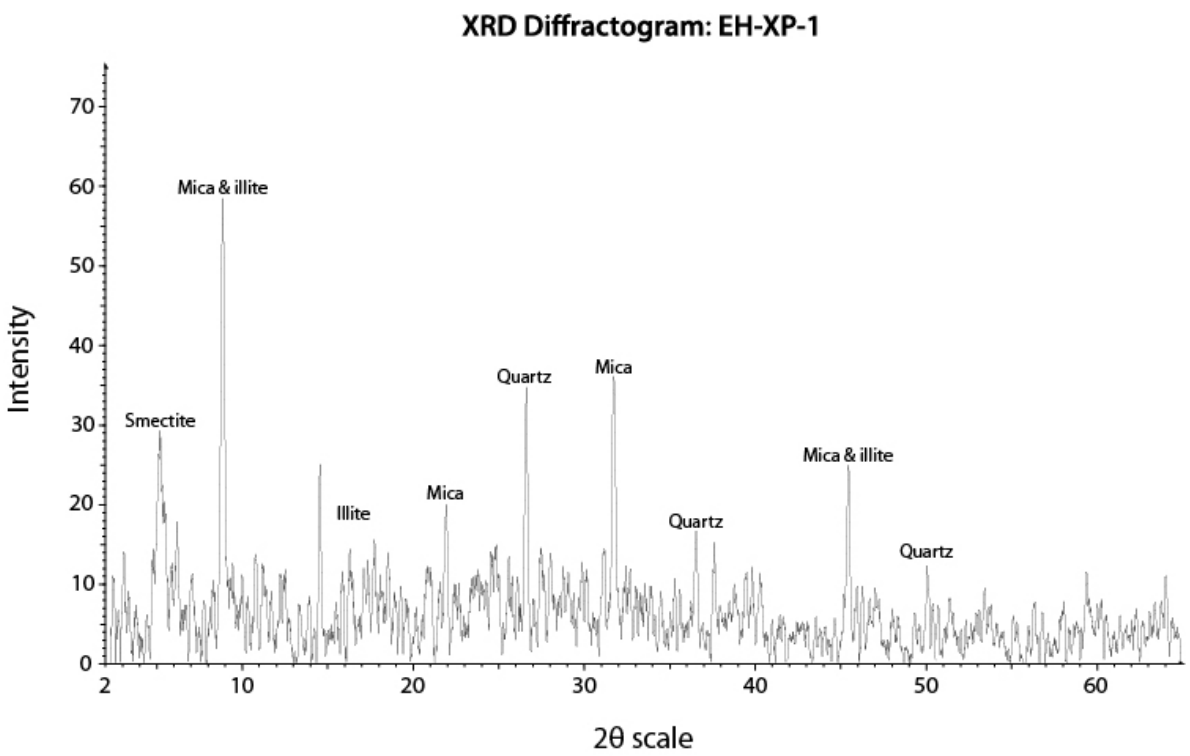

Fig. A2. XRD analysis of sample EH-XP-1 summarised in Table 1. Notably, the comparatively significant ca. $10^{\circ}$ (2Theta) phyllosilicate (mica and illite) peak could wholly or in part represent the illite-type structure characteristic of thermal decomposition products of major primary clay minerals.

\section{XRD Diffractogram: EH-XP-2}

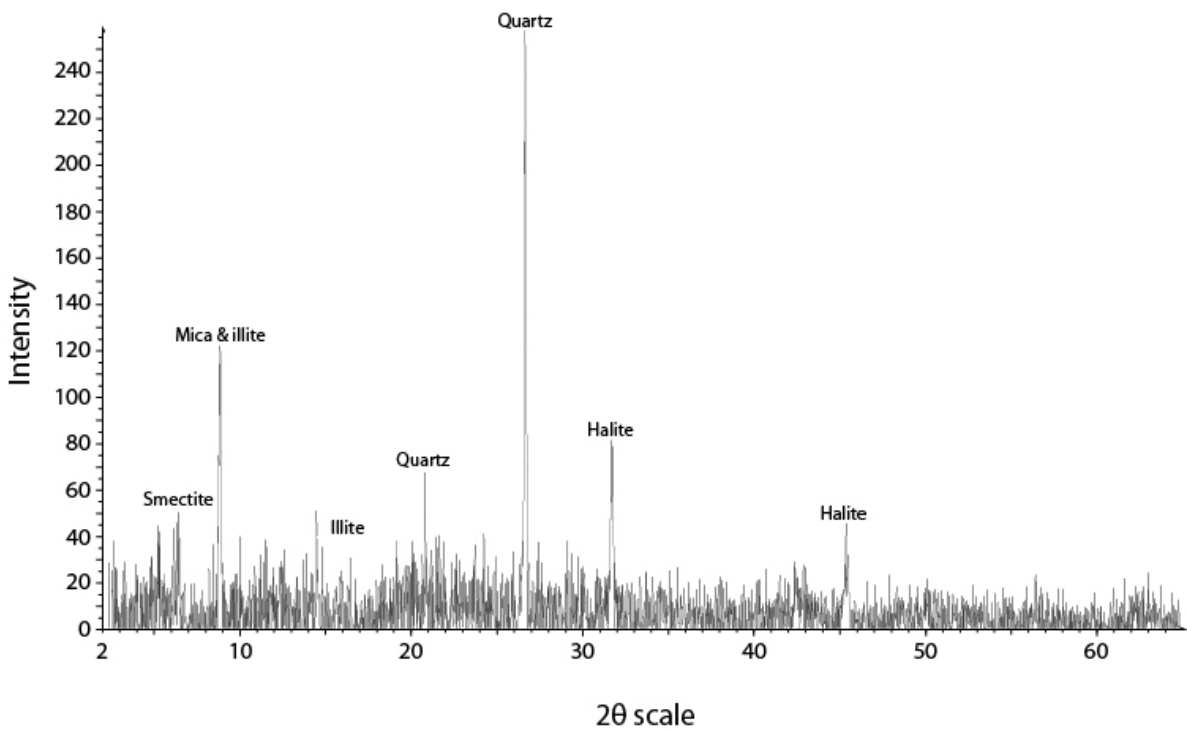

Fig. A3. XRD analysis of sample EH-XP-2 summarised in Table 1. Notably, the comparatively significant ca. $10^{\circ}$ (2Theta) phyllosilicate (mica and illite) peak does wholly or in part represent the illite-type structure characteristic of thermal decomposition products of major primary clay minerals. 


\section{Supplementary material related to this article is available online at: http://www.solid-earth.net/ 3/97/2012/se-3-97-2012-supplement.pdf.}

Acknowledgements. We are greatly indebted to Instituto Geográfico Nacional, in particular Maria José Blanco, for support during fieldwork on El Hierro and Vincente Soler of Consejo Superior de Investigaciones Científicas for help with sampling the earliest "floating stones", during the initial phase of the events. The Consejo del Medio Natural, Cabildo de El Hierro, kindly permitted us to take samples. Hans Harrysson and Stefan Sopke are thanked for laboratory support. The Swedish and the German Science Foundations (VR and DFG), the ERC grant EVOKES and the Center for Natural Disaster Science (CNDS) Sweden are thanked for generous financial support. We are also extremely grateful for comments on the manuscript posted through the Solid Earth Discussions online system and sent to us by mail, as well as those by journal reviewers Raphael Paris and Francisco José Pérez Torrado.

Edited by: M. Heap

\section{References}

Aparicio, A., Bustillo, M. A., Garcia, R., and Araña, V.: Metasedimentary xenoliths in the lavas of the Timanfaya eruption (17301736, Lanzarote, Canary Islands): metamorphism and contamination processes, Geol. Mag., 143, 181-193, 2006.

Aparicio, A., Tassinari, C. C. G., Garcia, R., and Araña, V.: Sr and $\mathrm{Nd}$ isotope composition of the metamorphic, sedimentary and ultramafic xenoliths of Lanzarote (Canary Islands): Implications for magma sources, J. Volcanol. Geotherm. Res., 189, 143-150, 2010.

Araña, V. and Ibarrola, E.: Rhyolitic pumice in the basaltic pyroclasts from the 1971 eruption of Teneguía volcano, Canary Islands, Lithos, 6, 273-278, 1973.

Berg, S.: Constraining crustal volatile release in magmatic conduits by synchrotron X-ray $\mu$-CT. Examensarbete vid Institutionen för geovetenskaper, Uppsala Universitet, ISSN 1650-6553 Nr. 225, 2011.

Brun, F., Mancini, L., Kasae, P., Favretto, S., Dreossi, D., and Tromba, G.: Pore3D: A software library for quantitative analysis of porous media: Nucl. Instr. Methods Phys. Res. Sect. A, 615, 326-332, 2010.

Carracedo, J. C., Rodríguez Badiola, E., Guillou, H., De La Nuez, J., and Pérez Torrado, F. J.: Geology and volcanology of La Palma and El Hierro, Western Canaries, Estudios Geológicos, 57, 1-124, 2001.

Coello, J. J.: Sobre el origen de la "restingolita", Actualidad Volcánica de Canarias- Noticias, 10 Oct 2011, http://www.avcan. org/?m=Noticias\&N=911, 2011.

Collier, J. S. and Watts, A. B.: Lithospheric response to volcanic loading by the Canary Islands: constraints from seismic reflection data in their flexural moat, Geophys. J. Int., 147, 660-676, 2001.
Criado, C. and Dorta, P.: An unusual "blood rain" over the Canary Islands (Spain) The storm of January 1999, J. Arid. Environ., 55, 765-783, 1999.

Gee, M. J. R., Masson, D. G., Watts, A. B., and Allen, P. A.: The Saharan debris flow: an insight into the mechanism of long runout submarine debris flows, Sedimentology, 46, 317-335, 1999.

Gimeno, D.: Informe realizado para el Ayuntamiento de El Pinar, El Hierro, Islas Canarias, sobre un piroclasto de la erupción en curso, Internal report, 10 Oct 2011.

Guillou, H., Carracedo, J. C., Pérez Torrado, F. J., and Rodríguez Badiola, E.: K-Ar ages and magnetic stratigraphy of a hotspotinduced, fast grown oceanic island: El Hierro, Canary Islands, J. Volcanol. Geotherm. Res. 73, 141-155, 1996.

Hammer, J. E., Cashman, K. V., Hoblitt, R. P., and Newman, S.: Degassing and microlite crystallization during pre-climactic events of the 1991 eruption of Mt. Pinatubo, Philippines, Bull. Volcanol., 60, 355-380, 1999.

Hansteen, T. H. and Troll, V. R.: Oxygen isotope composition of xenoliths from the oceanic crust and volcanic edifice beneath Gran Canaria (Canary Islands): consequences for crustal contamination of ascending magmas, Chem. Geol., 193, 181-193, 2003.

Hansteen, T. H., Klügel, A., and Schmincke, H.-U.: Multi-stage magma ascent beneath the Canary Islands: evidence from fluid inclusions, Contrib. Mineral. Petrol., 132, 48-64, 1998.

Harris, C., Smith, H. S., and le Roex, A. P.: Oxygen isotope composition of phenocrysts from Tristan da Cunha and Gough Island lavas: Variation with fractional crystallization and evidence for assimilation, Contrib. Mineral. Petrol., 138, 164-175, 2000.

Harris, C., Whittingham, A. M., Milner, S. C., and Armstrong, R. A.: Oxygen isotope geochemistry of the silicic volcanic rocks of the Etendeka/Paraná Province: source constraints, Geology, 18, 1119-1121, 1990.

Hoernle, K. A.: Geochemistry of Jurassic ocean crust beneath Gran Canaria (Canary Islands): implications for crustal recycling and assimilation, J. Petrol., 39, 859-880, 1998.

IGN; Instituto Geográfico Nacional, Ministerio de Fomento, Servicio de Información Sísmica, http://www.ign.es/ign/resources/ volcanologia/HIERRO.html, 2011.

Klügel, A., Hansteen, T. H., and Schmincke, H.-U.: Rates of magma ascent and depths of magma reservoirs beneath La Palma (Canary Islands), Terra Nova, 9, 117-121, 1997.

Klügel, A., Schmincke, H.-U., White, J. D. L., and Hoernle, K. A.: Chronology and volcanology of the 1949 multi-vent rift-zone eruption on la Palma (Canary Islands), J. Volcanol. Geotherm. Res., 94, 267-282, 1999.

Krastel, S. and Schmincke, H.-U.: Crustal structure of northern Gran Canaria deduced from active seismic tomography, J. Volcanol. Geotherm. Res., 115, 153-177, 2002.

McLeod, P. and Sparks, R. S. J.: The dynamics of xenolith assimilation, Contrib. Mineral. Petrol., 132, 21-33, 1998.

Pellicer, J. M.: Estudio geoquímico del vulcanismo de la isla del Hierro, Archipiélago Canario, Estudios Geol., 35, 15-29, 1979.

Perugini, D., Poli, G., Petrelli, M., De Campos C. P., and Dingwell, D. B.: Time-scales of recent Phlegrean Fields eruptions inferred from the application of a "diffusive fractionation" model of trace elements, Bull. Volcanol. 72, 431-447, 2010.

Polacci, M., Mancini, L., and Baker, D. R.: The contribution of synchrotron X-ray computed microtomography to under- 
standing volcanic processes, J. Synchrotron Rad., 17, 215-221, doi:10.1107/S0909049509048225, 2010.

Rodriguez-Badiola, E., Pérez-Torrado, F. J., Carracedo, J. C., and Guillou, H.: Geoquímica del edificio volcanic Teide-Pico Viejo y las dorsales noreste y noroeste de Tenerife, in: Los volcanes del Parque Nacional del Teide/El Teide, Pico Viejo y las dorsales activas de Tenerife. Madrid: Organismo Autónomo Parques Nacionales Ministerio De Medio Ambiente, edited by: Carracedo, J. C., 129-186, 2006.

Savin, S. M. and Epstein, S.: The oxygen and hydrogen isotope geochemistry of ocean sediments and shales, Geochim, Cosmochim. Acta, 34, 43-63, 1969.

Schmincke, H.-U. and Graf, G.: DECOS / OMEX II, Cruise No. 43. METEOR-Berichte 20001, Univ. Hamburg, 1-99, 2000.

Sheppard, S. M. F. and Harris, C.: Hydrogen and oxygen isotope geochemistry of Ascension Island lavas and granites: variation with crystal fractionation and interaction with seawater, Contrib. Mineral. Petrol., 91, 74-81, 1985.

Sparks, R. S. J. and Marshall, L. A.: Thermal and mechanical constraints on mixing between mafic and silicic magmas, J. Volcanol. Geotherm. Res. 29, 99-124, 1986.

Stillman, C. J., Bennell-Baker, M. J., Smewing, J. D., Fuster, J. M., Muñoz, M., and Sagredo, J.: Basal complex of Fuerteventura (Canary Islands) is an oceanic intrusive complex with rift-system affinities, Nature, 257, 469-471, 1975.

Stroncik, N. A., Klügel, A., and Hansteen, T. H.: The magmatic plumbing system beneath El Hierro (Canary Islands): constraints from phenocrysts and naturally quenched basaltic glasses in submarine rocks, Contrib. Mineral. Petrol., 157, 593-607, 2009.
Sumita, M. and Schmincke, H.-U.: Tephra event stratigraphy and emplacement of volcaniclastic sediments, Mogán and Fataga stratigraphic intervals, Part I: mineral and chemical stratigraphy of volcaniclastic units and correlation to the subaerial record, in: Proc. ODP, Sci. Results, 157, College Station, TX (Ocean Drilling Program), edited by: Weaver, P. P. E., Schmincke, H.-U., Firth, J. V., and Duffield, W., 219-266, doi:10.2973/odp.proc.sr.157.114.1998, 1998.

Troll, V. R. and Schmincke, H.-U.: Magma mixing and crustal recycling recorded in ternary feldspar from compositionally zoned peralkaline ignimbrite "A", Gran Canaria, Canary Islands, J. Pet., 43, 243-270, 2002.

Troll, V. R., Sachs, P. M., Schmincke, H.-U., and Sumita, M.: The REE-Ti mineral chevkinite in comenditic magmas from Gran Canaria, Spain: a SYXRF-probe study, Contrib. Mineral. Petrol., 145, 730-741, 2003.

Vennemann, T. W. and Smith, H. S.: The rate and temperature of reaction of CLF3 with silicate minerals, and their relevance to oxygen isotope analysis, Chem. Geol., 86, 83-88, 1990.

Wiesmaier, S.: Magmatic differentiation and bimodality in oceanic island settings - implications for the petrogenesis of magma in Tenerife, Spain, PhD thesis, University of Dublin, Trinity College, 2010.

Ye, S., Canales, J. P., Rhim, R., Danobeitia, J. J., and Gallart, J.: A crustal transect through the northern and northeastern part of the volcanic edifice of Gran Canaria, Canary Islands, J. Geodyn., 28, 3-26, 1999. 